\title{
Medicinal Rice and its Medicinal Values
}

\author{
R. Pushpam*, S. R. Mythili and T. C. Nikitha
}

Tamil Nadu Agricultural University, Coimbatore, India

*Corresponding author

\section{A B S T R A C T}

\section{Keywords}

High blood pressure, Body balance, Digestive system disorders, Diarrhoea in children, Skin inflammation

Article Info

Accepted:

15 September 2019

Available Online:

10 October 2019
With the advent of the Green revolution high yielding varieties had their upper hand and the medicinal properties of landraces and the traditional rice varieties became an ignored experience. Traditional rice varieties are a consortium of desirable traits such as high yielding, tolerance to extreme stress conditions and also are rich in nutritive and therapeutic value. They have reduced sugar content and are preferred by people who are trying to regulate their sugar intake or suffering from diabetics, overweight. They are rich in vitamins, fibre and glutamic acid. In order to lead an energetic, juvenile and long life saints have recommended people to consume traditional varieties. In India, Ayurvedha and Unani systems of medicine rely on the therapeutic properties of rice. Traditional rice has been extensively used to control high blood pressure, body balance, digestive system disorders, diarrhoea in children, skin inflammation, regulating blood sugar level and certain other specific diseases.

\section{Introduction}

\section{Rice is life}

Rice is consumed as a staple food by about 90 per cent of Asians and known as grain of life. Rice has $80 \%$ carbohydrates, $3 \%$ fat, $3 \%$ fibre and $8 \%$ protein (Juliano, 1985). It serves the energy needs of about 2 billion people in Asia alone. The present scenario of junk food consumption which satisfies the taste buds of people has bought an alarming rise in lifestyle-related diseases. Indian nutritionists often recommend drug molecule from food which supplements the nutritional requirement. Unlike any other country, in India we have a rich source of diversity in rice which include more than 2 lakh rice varieties (Mohammed Ashraf and Subbalakshmi Lokanadan, 2017). With the advent of the 
Green revolution high yielding varieties had their upper hand and the medicinal properties of landraces and the traditional rice varieties became an ignored experience. Traditional rice varieties are a consortium of desirable traits such as high yielding, tolerance to extreme stress conditions and also are rich in nutritive and therapeutic value. They have reduced sugar content and are preferred by people who are trying to regulate their sugar intake or suffering from diabetics, overweight. They have higher amount of glutamic acid, fibre and vitamins. Traditional varieties have been regarded as an energetic food for people and were recommended by saints of having the medicinal values to keep juvenile and long life (Bhat and Riar, 2015).

\section{Human vs health}

The modern diet has undergone many drastic changes in recent years. Ailments like obesity, food poisoning, dehydration, cardiac problems, diabetics, arthritis has been seen to be increased profoundly in younger generations due to rapid changes in the pattern of food consumption as the country is becoming more urbanized and industrialized. Health is reflected in the well-being of physical, mental and social aspects. Traditional nutrition is a science to provide basic nutrition to the body.

Non-communicable disease (NCD) are now responsible for around 41 million deaths per year. According to world health organization due to less nutritious food younger generations are reported with more eye problems, depression, high blood pressure $(12.8 \%$ of total deaths in world, 2019) Alzheimer's disease, kidney problem, obesity (600 million peoples have BMI greater than 30), diabetics (1.6 million death) than ancestors. In olden days people consumed different varieties of rice which is the secret for their healthy lifestyle. Different varieties of rice landraces have many nutritional and medicinal properties which can be again restored into our lifestyle to reduce diseases naturally without any extra care. Also, it will strengthen the food security not only by utilizing the conservation but also conservation by utilization.

\section{Medicinal rice - An extensive cure}

In India, Ayurvedha and Unani systems of medicine rely on the therapeutic properties of rice. Traditional rice has been extensively used to control high blood pressure, body balance, digestive system disorders, diarrhoea in children, skin inflammation, regulating blood sugar level and certain other specific diseases.

\section{Medicinal rice varieties a store house of Nutrients}

In India, Ayurvedha and Unani systems of medicine rely on the therapeutic properties of rice. Traditional rice has been extensively used to control high blood pressure, body balance, digestive system disorders, diarrhoea in children, skin inflammation, regulating blood sugar level and certain other specific diseases. Medicinal rice varieties a storehouse of Nutrients. Rice cultivation is a major source of income for most of peoples. Rice is nutritive, salubrious, diuretic, which ease digestion. It is considered to be a starchy food and source of carbohydrates also contain a small amount of protein. Rice has unequalled to any other crop for its irreplaceability and special qualities, it provides internal harmony and excellent food to include in a balanced diet. Using the medicinal rice varieties in our lifestyle would greatly reduce the dependence on external medicine. Rice seeds are taken internally to treat urinary dysfunction, to reduce excessive lactation. Germinated seeds to treat poor appetite and bloating. 
Special variety of Basmathi dark rice is red rice and is rich in iron. Brown rice is rich in calcium which relaxes nerve problems. To relieve the inflamed exterior, pharmacopoeia in India recommend rice water as an ointment. Laicha rice variety is used to prevent laicha disease a type of skin infection. Sticky rice reduces heartburns, stomach upset, nausea. Brown rice has the properties to treat warts, breast problems, stomach cancer, it also has magnesium content which is used to treat Alzheimer disease. It is also used to counteract high blood pressure. It also has niacin, vitamin D, calcium, fibre, iron, thiamine and riboflavin. Nowadays interest focussed on oryzanol, tocopherol, tocotrienols- antioxidant properties. Not only rice, the by-products from ever-growing rice provide several helpful and worthy products. The decoction of rice straw is suggested to treat kidney and gall bladder stones and also cures urinary disorders (Mohammed Ashraf and Subbalakshmi Lokanadan, 2017).

The phytochemical analysis indicated Mapillai samba rice had highest vitamin $\mathrm{E}$ content $(26.73 \pm 0.49 \mu \mathrm{g} / \mathrm{g})$, whereas Kala namak rice showed highest phenolic content (43.19 \pm 0.54 $\mathrm{mg} / \mathrm{g}$ ). Higher Total Phenol Content was observed for Iluppai poo samba $34.61 \pm 0.75$ mg/100g (Venkatesh Rajendran et al., 2018). Rice bran derived arabinoxylans have potent chemotherapeutic effect against breast cancer (Ghoneum et al., 2014). The rice bran extracts of four varieties Njavara, Yamini, Jyothi, Vasumathi rice varieties have antioxidant potential for brain carcinoma as well as potent nutraceutical (Rao et al., 2010).

\section{Literatures about medicinal rice}

Medicinally rice is used as diuretic (excess amount of salt is expelled from the body), spermatopoietic (promotes formation of semen), refrigerant, increases the eye vigour, cosmetic and tonic. It soothes the voice. It has high efficacy in treating fever and ulcer. Rice also serves as a good disinfectant and an antitoxin. Susruta Samhita, a representative work of Ayurveda has recommended Sastika rice for daily consumption.

Writings in Charaka Samhita (Ray and Gupta, 1965) say that a wild rice plant called Nivara is used to treat haematuria. Tandula is often used for rejuvenation and as vitalizer. During the 7th or 9th month of pregnancy kappa kar rice is served for the mother as it reduces the risk of anaemia. Some of the rice varieties from West Bengal like Bhat moori, improves blood circulation, Parmai-sal enhances our strength and Kabiraj-sal fastens the recovery of convalescing patients.

Based on some other literature references, to maintain stamina Bhama, a red rice variety from Chhattisgarh and Jharkhand is highly valued by the tribals. For lactating mothers, Bhajily, a variety from Chhattisgarh and Bihar is given to improve their health. An aromatic variety called Kala jira from koraput district of Orissa is given during the springtime and it provides great strength. A red rice variety, Lohitaka has excellent medicinal value. It improves eyesight, gives a cooling effect to the body and used as a tonic. Some rice varieties such as Njavara, Gathuran can be given to the aged persons for the relaxation and rejuvenation of weak muscles. It also serves as a cure for neurological problems, arthritis and rheumatism.

In Tamil Nadu, Annamazhagi rice has the property to cure fevers and body heat. To cure skin diseases and to regulate the blood pressure, a salt tolerant black rice variety Kalanamak is used. To maintain the sugar level under control and to cure piles regular consumption of Karuthakar rice is recommended. Kattuyanam rice controls diabetics. Kodai samba rice cures Vatha related diseases. A dark coloured rice variety 
Karunkuruvai is used to cure skin ailments and venomous bites and stings. Gundu samba is for better digestion and skin related diseases. Siddha physicians valued karunguruvai as it is rich in protein, fat and phosphorus. Lactating mothers and pregnant women are suggested to consume Neelam samba as it has enriched amount of calcium. Potassium is rich in Kalanamak rice and is suggested for people having high blood pressure. To provide more strength and stamina, Mappillai samba which is rich in carbohydrates and crude fibre is consumed. Traditional rice varieties have low Glycemic Index than the recently released modern varieties. It eliminates the risk of Diabetics (GI of Karungkuruvai, Kavuni, Kalanamak and Kullakar are in range of 50-55 which is of low GI; Kudaivazhai and Mapillai Samba has medium range of GI 66-70) (Mohanty et al., 2014).

Table.1

\begin{tabular}{|c|c|}
\hline Variety & Medicinal property \\
\hline Sali rice & $\begin{array}{l}\text { Sali rice roots aids in natural rejuvenation( Brahma Rasayana) } \\
\text { Used to cure piles and checks haemorrhoids bleeding } \\
\text { Sali rice mixed with ghee is to skin burns applied } \\
\text { Sali with barley cures anaemia } \\
\text { Paste made from Sali rice with ghee used against Fractures } \\
\text { Red Sali rice powder with milk and honey used against irregular uterine } \\
\text { bleeding (meno- metrorrhagia). } \\
\text { Increases milk in mother } \\
\text { Red Sali rice gruel cures pain in the head, pelvis and chest }\end{array}$ \\
\hline Sashtika rice & $\begin{array}{l}\text { Sashtika rice when consumed with ghee and milk helps to delay } \\
\text { degenerative process in the body. } \\
\text { Tablets made from sashtika rice is used as aphrodisiac } \\
\text { Sashtika and barley is used to cure urinary problems such as premeha } \\
\text { Treats stomach problems (gruel made from Sashtika rice soaked in cow } \\
\text { urine and consumed with milk) }\end{array}$ \\
\hline Laja rice & $\begin{array}{l}\text { Sensation such as vomiting, burning,thirsty and debility can be cured by } \\
\text { consuming saturated drink from laja rice } \\
\text { Dish made from laja rice powder, sugar,honey,ghee and kosakar, is taken } \\
\text { against Diarrhoea } \\
\text { Laja rice powder with honey and ghee gives relisf against vomiting. } \\
\text { Internal bleeding can be cured by consuming drink made from laja rice } \\
\text { powder with ghee and honey. }\end{array}$ \\
\hline Nivara rice & $\begin{array}{l}\text { Oil: Used to treat age related problems such as osteoarthritis (cervical } \\
\text { spondilytis), rheumatoid arthritis, back pains, paralysis, neurological and } \\
\text { muscular disorders } \\
\text { Increases weight in babies and also cures ulcers in abdomen } \\
\text { Used against skin diseases such as skin lesions and Psoriasis } \\
\text { Used to treat against snake poison. } \\
\text { Gruel made from the rice along with meat is used to gain body weight } \\
\text { Nivara rice paste mixed with Coconut and sesame oil is used against polio } \\
\text { Raw rice soaked in milk and roasted in cow milk is taken against }\end{array}$ \\
\hline
\end{tabular}




\begin{tabular}{|l|l|}
\hline & $\begin{array}{l}\text { Haemorrhoids } \\
\text { Flakes of nivara Rice with asvagandha and sugar is used to stimulate } \\
\text { sexual desire } \\
\text { Root Decoction of Nivara given to children with urinary complaints. }\end{array}$ \\
\hline Karung kavuni & $\begin{array}{l}\text { Used to treat Elephantiasis } \\
\text { Dilutes the bad cholesterol } \\
\text { Used to treat dog bites }\end{array}$ \\
\hline $\begin{array}{l}\text { Aalcha } \\
\text { Baissor }\end{array}$ & $\begin{array}{l}\text { Aalcha cures achens,cures skin abscess in childrens } \\
\text { Baissor cures long term headaches and also cures an acquired brain injury } \\
\text { such as stroke(epilepsy) } \\
\text { Rheumatism } \\
\text { Karhani } \\
\text { Kalimoonch }\end{array}$ \\
$\begin{array}{l}\text { Maharaji } \\
\text { Bhajari }\end{array}$ & $\begin{array}{l}\text { Paralysis } \\
\text { Skin diseases } \\
\text { As a post partum tonic for women after child birth } \\
\text { Placenta resumption in cows } \\
\text { Renewal of placenta in cows }\end{array}$ \\
\hline Aalcha, Nagkesar & Skin problems \\
\hline
\end{tabular}

Maharaji, a Chhattisgarh rice variety which is known to provide strength and stamina to women after giving birth. For the treatment of acquired brain injury such as stroke(epilepsy), Baisoor rice variety is consumed. Pregnant women are suggested to intake Laicha rice variety for healthy delivery. A rice variety, Baisoor has the property to treat headache and boils. For treating the skin ailments, fungal infections such as ringworm, eye-related infection such as conjunctivitis, itching Baisoor variety is recommended. It is also used as a face pack with neem leaves. The following are some of the kinds of rice which have medicinal values.

Thus, different rice landraces have numerous nutritional and therapeutic properties which can be again restored into our lifestyle to lessen ailments normally with no additional consideration. Also, it will strengthen the food security not only by utilizing the conservation but also conservation by utilization. But with the advent of hybrid revolution, farmers are happily accepting the new varieties for higher yield. Thus millions of years of genetic diversity and germplasm heritage are vanishing forever. Hence urgent action is warranted to collect and save these unique rice varieties for the benefit of posterity.

\section{References}

Ahuja, U., S. C. Ahuja, Rashmi Thakrar, and R.K. Singh. 2018. Rice- A Nutraceutical. Asian Agri-History,12 (2) : 93-108.

Bhat F.M and C.S.Riar. 2015 Health Benefits of Traditional Rice Varieties of Temperate Regions. Medicinal and Aromatic Plants, 4: 198.

Chaudhari, P.C., N.Tamrakar, Laxmi Singh, A. Tandon and Deepak Sharma. 2018. Rice nutritional and medicinal properties: A review article. Journal of Pharmacognosy and Phytochemistry, 7(2) : 150-156

Ghoneum, M. N.K., B.E. Din, D.A. Ali and M.A.E. Dein. 2014. Modified Arabinoxylan from Rice Bran, MGN-3/Biobran, Sensitizes Metastatic Breast Cancer Cells to Paclitaxel. In vitro Anticancer research, 34: 81-88

Juliano, B.O., 1985. Rice Chemistry and Technology.American Association of 
Cereal Chemists. USA, pp: 757.

Mohammed Ashraf, A and Subbalakshmi Lokanadan. 2017. A Review of Rice Landraces in India and its Inherent Medicinal Values - The Nutritive Food Values for Future, International Journal of Current Microbiology and Applied Sciences, 6(12) : 348-354.

Mohanty R. B., T. Panda, B. K. Tripathy. 2014. Nutritional and therapeutic properties of indigenous paddy varieties (IPVs), Final Progress Report of the project implemented by the Centre for Indian Knowledge Systems (CIKS), Chennai, India for the period November 2013 to September 2014.

Rao, A.S.V., C, S. G. Reddy, P.P. Babu and A.R. Reddy, 2010. The antioxidant and antiproliferative activities of methanolic extract from Njavara Rice Bran. BMC. Journal of Alternative and Complementary Medicine, 4: 1-10.

Ray. P and H.N. Gupta, 1965 Caraka Samhita (A scientific synopsis)- Second Edition, 1980.

Sharma, P.V. 1996. Classical Uses of Medicinal Plants. Chaukhamba Vishwabharati, Varanasi, Uttar Pradesh, India. 848 pp.

Venkatesh Rajendran, Hari Priya Sivakumar Iswarya Marichamy Sathish Sundararajan Sathishkumar Ramalingam. 2018. Phytonutrients analysis in ten popular traditional Indian rice landraces (Oryza sativa L.), Journal of Food Measurement and Characterization, 2, 11694-018-9877.

\section{How to cite this article:}

Pushpam, R., S. R. Mythili and Nikitha, T. C. 2019. Medicinal Rice and its Medicinal Values. Int.J.Curr.Microbiol.App.Sci. 8(10): 2090-2095. doi: https://doi.org/10.20546/ijcmas.2019.810.243 